\title{
Salmonella spp. Isolated by Miniaturized Most Probable Number and Conventional Microbiology in Poultry Slaughterhouses
}

\author{
Ligiani Mion', Luana Parizotto', Lilian Andriva dos Santos', \\ Bruna Webber', Isabel Cristina Cisco', Fernando Pilotto', \\ Laura Beatriz Rodrigues', Vladimir Pinheiro do Nascimento² \& Luciana Ruschel dos Santos'
}

\begin{abstract}
Background: Salmonella spp. are frequently isolated from fowls, and their detection in poultry products varies according to the breeding system and the slaughtering process, bringing risks to the consumer and compromising the marketability. The control of Salmonella in poultry slaughterhouses is based on the detection of bacteria, but the quantification of the agent would be important in assessing risk, as well as in obtaining data to determine the capacity of each step of the process to decrease or increase bacterial contamination. The aims of this study were to propose a method for the quantification of Salmonella in poultry slaughterhouses, frequency of isolation and serovars identified.

Materials, Methods \& Results: Twenty-one broiler flocks from seven federally inspected slaughterhouses in southern Brazil, totaling 1,071 samples, were assessed by miniaturized most probable number (mMPN) and conventional microbiology. The samples were collected in triplicate at 17 points, which included cloacae, transportation cages before and after sanitization, water (scald tank, supply, pre-chiller and chiller), and carcasses (before and after scalding, defeathering, rinsing, evisceration, final rinsing, chilling at $4^{\circ} \mathrm{C}$, and freezing at $-12^{\circ} \mathrm{C}$ for $24 \mathrm{~h}, 30$ and 60 days). Typical Salmonella colonies were submitted to TSI, LIA, SIM, urea, and polyvalent anti-O antiserum tests, and to final identification by Microarray by Check\&Trace. Nine of the $1,071(0.83 \%)$ samples analyzed by mMPN and by conventional microbiology were positive for Salmonella and the following serovars were identified: Anatum, Brandenburg, Agona, Tennessee, Bredeney, Schwarzengrund and Infantis.

Discussion: This positive rate was lower than that described by other authors, whose rates ranged from 3\% and 39\% for the isolation of Salmonella spp. from different sources, such as slaughterhouses and retail sales in samples collected in Brazil. The low frequency of isolation of Salmonella in this study can be attributed to the efficiency of control systems used from the field to the slaughterhouse, such as Good Manufacturing Practices (GMP) and Sanitation Standard Operating Procedures (SSOP), which are HACCP requirements. Also, when slaughtering technology actions are properly managed, such as water replacement and temperatures lower than $4^{\circ} \mathrm{C}$ in the chiller, the initial contamination by Salmonella spp. can be reduced, with a decline in contamination from $70 \%$ to $20 \%$, and with a reduction in the contamination of broiler carcasses after chilling from $15.8 \%$ to $3.3 \%$. On the other hand the contamination of carcasses by Salmonella before pre-chilling and in post-chilling might be due to the automated system, inadequate temperatures during chilling, and inappropriate water chlorination in the assessed meat-packing plant. Of the 17 points evaluated, seven were positive for Salmonella, especially the cages after sanitization and frozen carcasses. The contamination by Salmonella spp. in transportation cages after sanitization indicates inefficiency of the automated system as well as possible bacterial resistance to the sanitizers used in SSOP while the isolation in carcasses frozen for $24 \mathrm{~h}$ and 60 days demonstrates the thermal resistance of the bacterium to a conservation method widely used in the food industry. In this work, just one of the nine positive samples for Salmonella was identified by conventional methods (CM) and mMPN. The discrepancy between methods can be explained by the heterogeneous distribution of Salmonella and other bacteria in naturally contaminated samples. Samples that were positive in the qualitative test but negative in the mMPN protocol could have had a number of Salmonella below the detection amount.
\end{abstract}

Keywords: Salmonella, mMPN, serovars, poultry slaughterhouses. 


\section{INTRODUCTION}

Salmonella spp. are frequently isolated from fowls, and their detection in poultry products varies according to the breeding system and the slaughtering process, bringing risks to the consumer and compromising the marketability. Salmonella infections are classified as typical bird diseases, caused by serovars Pullorum and Gallinarum, and as paratyphoid diseases, which cause foodborne infections produced by over 2,500 nonspecific serovars. Of these, about $10 \%$ are isolated from birds, as the distribution of Salmonella spp. isolated from poultry is geographically variable and changes over the years [9].

The control of Salmonella in poultry slaughterhouses is based on the detection of bacteria, but the quantification of the agent would be important in assessing risk, as well as in obtaining data to determine the capacity of each step of the process to decrease or increase bacterial contamination.

Quantitative methods, such as the most probable number (MPN), allow estimating bacterial colonization based on statistical probabilities [16]. However, as it employs multiple tube series, the MPN method is time-consuming and financially unrewarding, and therefore impractical for hazard analysis, especially when several samples are analyzed simultaneously [5]. Enumeration methods using miniaturized most probable number (mMPN) with microtiter plates may be appropriate for microbial quantification, as they are quicker, more accurate and less expensive than the conventional MPN method [17].

The aims of this study were to propose a simplified method for the quantification of Salmonella in poultry slaughterhouses, to report its frequency of isolation, and to identify its serovars.

\section{MATERIALS AND METHODS}

\section{Sampling and collection}

The samples were collected from 7 federally inspected slaughterhouses (labeled A to G) in southern Brazil. Three collections were made in each slaughterhouse at different dates and from different flocks, totaling 21 samples, at the following points: cloacae, transportation cages before and after sanitization, water (scald tank; supply; pre-chiller and chiller), and carcasses before and after scalding, defeathering, washing, evisceration, final rinsing, before chilling, chilling at $4^{\circ} \mathrm{C}$, and freezing at $-12^{\circ} \mathrm{C}$ for $24 \mathrm{~h}, 30$ and 60 days. The collection points were sampled in triplicate, yielding 51 samples from each point, totaling 1,071 samples out of 21 collections.

Cloacal swabs were sampled from 300 broilers in each flock, using one swab for two broilers, yielding three pools of 50 swabs, stored in $50 \mathrm{~mL}$ bottles of buffered peptone water (BPW 1\%).

Three transport cages were sealed with official labels in each flock and sampled with a sponge moistened with neutralizing buffer $\left(3 \mathrm{M}^{\circledR}\right)$, rubbed across the inner side of the cages before and after washing and disinfection, totaling six samples per flock. The sponges were placed in the collection bags provided by the manufacturer and $50 \mathrm{~mL}$ of BPW $1 \%$ was added. The water was collected in $100 \mathrm{~mL}$ flasks containing $10 \%$ sodium thiosulfate. The carcasses were stored in sealed individual bags, kept under refrigeration and sent to the laboratory, where they were rinsed with 400 $\mathrm{mL}$ of BPW $1 \%$. Aliquots of $17.5 \mathrm{~mL}$ were obtained from each sample, of which $7.5 \mathrm{~mL}$ was submitted to mMPN [5,8] and $10 \mathrm{~mL}$ underwent conventional microbiology for Salmonella spp. isolation [10]. Typical Salmonella colonies were submitted to $\mathrm{TSI}^{2}, \mathrm{LIA}^{2}$, $\mathrm{SIM}^{2}$, urea ${ }^{2}$, and polyvalent anti-O antiserum tests ${ }^{3}$, and to final identification by Microarray by Check\&Trace ${ }^{1}$ equipment.

\section{Quantification of Salmonella spp. by Miniaturized Most Probable Number (mMPN)}

The mMPN method was used for quantification of Salmonella spp. This method consists of the same stages of conventional microbiology, but it uses 24 -well plates with a $2 \mathrm{~mL}$ capacity. Prior to the experiment, assays were conducted to determine the detection limit of mMPN in chicken meat samples artificially contaminated with Salmonella Enteritidis ATCC 13076, which corresponded to $0.13 \mathrm{MPN} / \mathrm{mL}$ [5]. Three $2.5 \mathrm{~mL}$ aliquots from a same sample were transferred to 24-well plates; afterwards, $0.5 \mathrm{~mL}$ of each well was serially diluted in BPW 1\% (1:5; 1:25 and 1:125). The plates were incubated at $37 \pm 1{ }^{\circ} \mathrm{C}$ for 16-20 h, placed in an orbital shaker for 3-5 min, and $20 \mu \mathrm{L}$ was transferred from each well to the corresponding well in plates containing $2 \mathrm{~mL}$ of Modified Semisolid Rappaport Vassiliadis (MSRV) ${ }^{2}$ [1], incubated for $24-48 \mathrm{~h}$ at $42^{\circ} \mathrm{C}$. Thereafter, the change in color from greenish blue in the MSRV medium 
to white or light blue indicated bacterial growth, confirmed by the seeding of the contents of these wells onto Rambach ${ }^{\circledR}$ agar $^{2}$. Colonies whose growth was compatible with Salmonella spp. were isolated on non-selective agar, incubated at $37 \pm 1^{\circ} \mathrm{C}$ for 18 $24 \mathrm{~h}$ and submitted to biochemical and serological confirmation as in conventional microbiology. Those wells in which the isolation of Salmonella spp. was confirmed by the polyvalent anti-O and biochemical tests were regarded as positive. The MPN per $\mathrm{mL}$ and the lower and upper bounds of the $95 \%$ confidence interval (95\% CI) were calculated. The MPN Calculator software was used to calculate the combinations of tubes obtained in this study, with positive tubes in series of 3 and inoculated sample volumes of 2; 0.5; 0.1 , and $0.02 \mathrm{~mL}$.
Regarding cage area and carcass weight, the MPN obtained from the combination of positive wells was converted to MPN/g or MPN/ $\mathrm{cm}^{2}$ using the following formulas:

$\mathrm{MPN} / \mathrm{g}=\mathrm{MPN} / \mathrm{mL}$ of the suspension $\mathrm{x}$ carcass weight in grams Diluent volume used

or:

$\mathrm{MPN} / \mathrm{cm}^{2}=\underline{\mathrm{MPN}} / \mathrm{mL}$ of the suspension $\mathrm{x}$ sampled area Diluent volume used

\section{RESULTS}

Nine of the $1,071(0.83 \%)$ samples evaluated by mMPN or conventional microbiology were positive for Salmonella in seven of the 17 sampled points (Table 1). The following serovars were identified: Anatum, Brandenburg, Agona, Tennessee, Bredeney, Schwarzengrund and Infantis.

Table 1. Salmonella serovars identified in poultry slaughtering by mMPN and conventional microbiology.

\begin{tabular}{cccc}
\hline Slaughterhouse & Sample & Serovar & Method* $^{*}$ \\
\hline B & Cloacal swabs & Anatum & CM and mMPN $(0.53 \mathrm{mMPN} / \mathrm{mL})$ \\
B & Carcass after defeathering & Brandenburg & CM \\
B & Carcass after rinsing & Brandenburg & $\mathrm{CM}$ \\
E & Cage after sanitization & Agona & $\mathrm{mMPN}\left(1.6 \mathrm{mMPN} / \mathrm{cm}^{2}\right)$ \\
F & Carcass frozen for 24 hours & Tennessee & $\mathrm{CM}$ \\
G & Cloacal swabs & Bredeney and & $\mathrm{mMPN}(0.42 \mathrm{mMPN} / \mathrm{mL})$ \\
G & Carcass after evisceration & Schwarzengrund & $\mathrm{CM}$ \\
G & Cage after sanitization & Bredeney & $\mathrm{CM}$ \\
G & Carcass frozen for 60 days & Infantis & mMPN $(0.17 \mathrm{mMPN} / \mathrm{g})$ \\
\hline
\end{tabular}

*CM $=$ conventional microbiology. mMPN $=$ miniaturized most probable number.

\section{DISCUSSION}

The prevalence of Salmonella spp. in poultry carcasses has decreased since the implementation of the Pathogen Reduction Program (PRP) for carcasses of broilers and turkeys, proposed by the Ministry of Agriculture, Livestock and Food Supply for all federally inspected slaughterhouses [3]. The data generated by the PRP allowed the adoption of specific measures for the reduction of Salmonella in positive flocks and targeted application of Hazard Analysis and Critical Control Points (HACCP) in slaughterhouses. According to the USDA [18], the investigation of Salmonella spp. is one of the recommended tools for assessing the adequacy of HACCP.
Therefore, the low frequency of isolation of Salmonella in this study can be attributed to the efficiency of control systems used from the field to the slaughterhouse, such as Good Manufacturing Practices (GMP) and Sanitation Standard Operating Procedures (SSOP), which are HACCP requirements. Also, when slaughtering technology actions are properly managed, such as water replacement and temperatures lower than $4^{\circ} \mathrm{C}$ in the chiller, the initial contamination by Salmonella spp. can be reduced with a decline in contamination from $70 \%$ to $20 \%$ [6], with a reduction in the contamination of broiler carcasses after chilling from $15.8 \%$ to $3.3 \%$ [16]. The contamination of carcasses by Salmonella before pre-chilling and in post-chilling might be due to the automated system, 
inadequate temperatures during chilling, and inappropriate water chlorination in the assessed meat-packing plant [11].

Of the 17 points evaluated, seven were positive for Salmonella, especially the cages after sanitization and frozen carcasses. The contamination by Salmonella spp. in transportation cages after sanitization indicates inefficiency of the automated system as well as possible bacterial resistance to the sanitizers used in SSOP while the isolation in carcasses frozen for 24 $\mathrm{h}$ and 60 days demonstrates the thermal resistance of the bacterium to a conservation method widely used in the food industry.

In this work, just one of the nine positive samples for Salmonella was identified by conventional methods (CM) and mMPN (Table 1). The discrepancy between methods can be explained by the heterogeneous distribution of Salmonella and other bacteria in naturally contaminated samples. Samples that were positive in the qualitative test but negative in the mMPN protocol could have had a number of Salmonella below the detection amount. The contrary is also possible because of failures in the detection methods. The quantification of Salmonella is usually conducted in artificially contaminated samples from different sources $[2,4,13]$ but no correlation is observed when naturally contaminated samples are assessed. Thus, the simultaneous use of these methods may be required to improve Salmonella isolation, minimizing the occurrence of false negative results [13] validated an mMPN method based on ISO 6579:2002 using MRSV and observed no significant difference between conventional MPN and mMPN [4], by comparing both methods, noted that the technique described by Fravalo et al. [8] proved to be efficient in the identification and quantification of Salmonella in poultry meat matrices, while the technique described by Pavic et al. [13] did not quantify the pathogen, due probably to problems associated with the acquisition of materials similar to those used in the original technique.

World Health Organization data [19] allow checking for serovars isolated in different countries and from different sources. In the present study, only serovar Infantis is cited among the five ones mostly associated with foodborne infections, ranking in third position. The isolation of $S$. Bredeney in cloacal swabs and in carcasses after evisceration, in the same flock, increases the possibility of cross-contamination during slaughter. Tennessee is not mentioned among the major serovars associated with foodborne diseases, with human cases notified only in Europe and in Japan. Brandenburg was isolated in three samples in 2004, but not from foods or animals. Schwarzengrund was isolated from foods, animals, and humans in the past decade while serovar $S .1,4[5], 12: \mathrm{i}$ :- was not found in humans in Brazil, but it was the fourth most isolated serovar in America in 2012.

\section{CONCLUSION}

The percentage of Salmonella spp. isolation less than $1 \%$ indicates the effectiveness of the controls used in poultry slaughterhouses sampled.

\section{MANUFACTURERS}

${ }^{1}$ Check\&Trace. R-Biopharm AG. Darmstadt, Germany.

${ }^{2}$ HiMedia ${ }^{\circledR}$ Laboratories. Mumbai, India.

${ }^{3}$ Difco ${ }^{\circledR}$ Laboratories. Sparks, MD, USA.

Acknowledgments. This study was supported by Fundação de Amparo à Pesquisa do Estado do Rio Grande do Sul (FAPERGS, Programa Pesquisador Gaúcho - PqG - Edital FAPERGS nº 004/2012).

Declaration of interest. The authors report no conflicts of interest. The authors alone are responsible for the content and writing of the paper.

\section{REFERENCES}

1 Baggensen D.L., Bagger J., Mogelmose V., Nielsen B., Svensmark B. \& Olsen J.E. 2001. Quantification of DT104 in slurry from infected pigs. In: 6th Workshop organized by CRL - Salmonella. (Bilthoven, Belgium). June 11-12, Report 284500019/2001. (5): 30-32.

2 Borsoi A., Moraes H.L.S., Salle C.T.P. \& Nascimento V.P. 2010. Número mais provável de Salmonella isoladas de carcaças de frango resfriadas. Ciência Rural. 40(11): 2338-2342.

3 Brasil. 2003. Ministério da Agricultura, Pecuária e Abastecimento - MAPA / Secretaria de Defesa Agropecuária. Programa de Redução de Patógenos Monitoramento Microbiológico e Controle de Salmonella sp. em Carcaças de Frangos e Perus. Diário Oficial da União. Brasília, Instrução Normativa nº 70, de 06 de outubro de 2003. Seção 1. pp.9-10. 
4 Colla F.L., Rodrigues L.B., Borsoi A., Dickel E.L., Nascimento V.P. \& Santos L.R. 2012. Isolamento de Salmonella Heidelberg em diferentes pontos da tecnologia de abate de frangos de corte. Arquivos do Instituto Biológico. 79(4): 603-606.

5 Colla F.L., Mion L., Parizotto L., Rodrigues L.B., Pilotto F., Dickel E.L., Nascimento V.P. \& Santos L.R. 2014. Miniaturized most probable number for the enumeration of Salmonella sp in artificially contaminated chicken meat. Brazilian Journal of Poultry Science. 16(1): 45-48.

6 Dickel E.L., Santos L.R., Rodrigues L.B., Valle S.F. \& Cecatti D. 2005. Ocorrência de Salmonella em abatedouros de aves com tecnologia totalmente automatizada (grande porte), semi automatizada (médio porte) e semi automatizada (pequeno porte). Higiene Alimentar. 19(131): 62-67.

7 Duarte D.A.M., Ribeiro A.R., Vasconcelos A.M.M., Santos S.B., Silva J.V.D., Andrade P.L.A. \& Falcão L. 2009. Occurrence of Samonella spp. in broiler chicken carcasses and their susceptibility to antimicrobial agents. Brazilian Journal of Microbiology. 40(3): 569-573.

8 Fravalo P., Hascoet Y., Le Fellic M., Quegumer S., Petton J. \& Salvat G. 2003. Convenient method for rapid and quantitative assessment of Salmonella enteric contamination: the mini-MSRV MPN technique. Journal of Rapid Methods and Automation in Microbiology. 11(2): 81-88.

9 Gast R., Guraya R. \& Guard-Bouldin J. 2007. Colonization of specific regions of the reproductive tract and deposition at different locations inside eggs laid by hens infected with Salmonella Enteritidis or Salmonella Heidelberg. Avian Diseases. 51(1): 40-44.

10 International Organization for Standardization. 2002. ISO 6579:2002. Microbiology of Food and Animal Feeding Stuffs - Horizontal Method for the Detection of Salmonella spp. Geneva, Switzerland: International Standards Organization. $27 \mathrm{p}$.

11 Lopes M., Galhardo J.A., Oliveira J.T., Tamanini R., Sanches S.F. \& Muller E.E. 2007. Pesquisa de Salmonella spp. e microrganismos indicadores em carcaças de frango e água de tanques de pré-resfriamento em abatedouro de aves. Semina. Universidade Estadual de Londrina. 28(3): 465-476.

12 Moreira G.N., Rezende C.S.M., Carvalho R.N., Mesquita S.Q.P., Oliveira N.A. \& Arruda M.L.T. 2009. Ocorrência de Salmonella sp. em carcaças de frangos abatidos e comercializados em municípios do estado de Goiás. Revista Instituto Adolfo Lutz. 67(2): 126-130.

13 Pavic A., Groves P.J., Bailey G. \& Cox J.M. 2010. A validated miniaturized MPN method, based on ISO 6579:2002, for the enumeration of Salmonella from poultry matrices. Journal of Applied Microbiology. 109(1): 25-34.

14 Ribeiro A.R., Kellermann A., Santos L.R., Bessa M.C. \& Nascimento V.P. 2007. Salmonella spp. in raw broiler parts: occurrence, antimicrobial resistance profile and phage typing of the Salmonella Enteritidis isolates. Brazilian Journal of Microbiology. 38(2): 296-299.

15 Santos D.M.S., Berchieri Jr.A., Fernandes S.A., Tavechio A.T. \& Amaral L.A. 2000. Salmonella em carcaças de frango congeladas. Pesquisa Veterinária Brasileira. 20(1): 39-42.

16 Silva N.A., Junqueira V., Silveira N.F.A., Taniwaki M.H., Santos R.F.S. \& Gomes R.A.R. 2010. Manual de métodos de análise microbiológica de alimentos e água. São Paulo: Livraria Varela, 624p.

17 Skovgaard N. 2005. Current topics in food microbiology. International Journal of Food Microbiology. 99: 107-111.

18 United States Department of Agriculture (USDA). 2013. Progress report on Salmonella and Campylobacter testing of raw meat and poultry products, 1998-2012. [Fonte: <http://www.fsis.usda.gov/wps/wcm/connect/8d792eef_ f44d_4ccb_8e25_ef5bdb4c1dc8/47>]. [Accessed September 2015].

19 World Health Organization (WHO). 2013. Global Foodborne Infections Network (GFN) Country Databank. [Fonte:< http://thor.dfvf.dk/pls/portal/GSS.YEAR_RANK_REP.show_parms.>]. [Accessed September 2015]. 